\title{
Differentiation of human limb buds in vitro(Abstract_要旨)
}

$\operatorname{AUTHOR}(S)$ :

Yasuda, Yoshiko

CITATION:

Yasuda, Yoshiko. Differentiation of human limb buds in vitro. 京都大学, 1976, 医学博士

ISSUE DATE:

1976-03-23

URL:

http://hdl.handle.net/2433/220945

RIGHT: 


\section{【147 】}

氏 名安思佳导

学位の種類医学博士

学位記番号論医 博 第 642 号

学位授与の日付昭和 51 年 3 月 23 日

学位授与の要件学 位 規則第 5 条第 2 項該 当

学位論文題目 Differentiation of human limb buds in vitro

（七ト四肢原基の培養下に和ける分化）

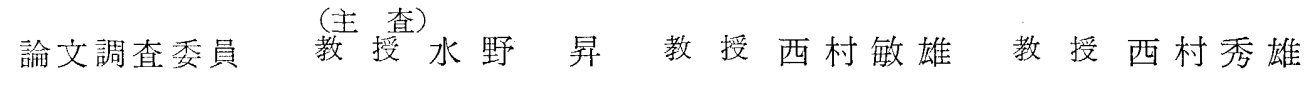

\section{論文内容の要旨}

サリドマイド事件は妊婦がその妊娠期間中に薬物を服用することがその胎児の先天性四肢奇形の誘因に なり得ることを警告した。一方実験動物に和いては妊娠中の物理的古るい性学的作用がその胎児の四 肢奇形誘発の原因となることは周知の事実であったが，実験動物に扔いて奇形を誘発した要因が必ずしも ヒトの場合に適用出来るとは限らず，種属差が存在することも広く知られていた。ヒトの四肢原基の培 羡を行い, 培盖下に括いて薬物を作用させた場合, 四肢原基がその薬物に対して感受性を持ち四肢の異常 発達が誘発されるか否かを検索することは, 薬物等の四肢の催奇形性をとトの場合に执いて検查する有用 な手段となり得ると考兄る。本研究はヒトの胎芽期の四肢原基の培盖を行い，培責下に扮いても四肢原 基が母体内に和ける様な一定の分化成長を示すか否か，合せてヒト四肢催奇形性検查の基準となり得るか 否かをみる目的で行った。人工妊娠中絶術に際して得られたヒト胎芽75例を用いた。これらの胎芽はス トリイター発育段階 (H.) 12 18 のもので, 推定排卵後日令28日から41日に相当した。術後直ちに, 抗 生物質混入アール氏緩衝液に胎芽を入れ培羕開始まで $4{ }^{\circ} \mathrm{C}$ に保った。培養室で新鮮なアール氏液で胎芽を 洗涤し, 双眼顕微鏡下で両側上下肢を切断した。培養は TC 199, 馬血清および 12 日ニワトリ泼抽出液を $2: 1: 1$ の割合で混和した $0.9 \%$ 寒天培地上で $38^{\circ} \mathrm{C}$ の条件下で行った。培地は 4 日毎に取換えた。培盖 4 日〜18日後にブアン氏液にて培養片を固定した。パラフィン包埋後 $8 \mu$ の連続切片を作製し交互の切片 にヘマトキシリンエオジン染色拉よびトルイジン青染色を施し組織標本を作製した後, 光学顕微鏡下で観 察を行った。培養片の分化成長の進行をみる目的で, 各段階の肢芽11例の培養前固定標本の組織切片と京 都大学医学部解剖学教室に所蔵されている正常胎芽組織標本 47 例とを合せて肢芽の観察を行った。培養片 を培養前の分化成長状態から第 1 段階（H．12 および 13）, 第 2 段階（H. 14 および 15）特よび第 3 段 階（H．16１8）に分類して検索を行った。第1段階の培着前の肢芽においては未分化間葉細胞和よび上 皮細胞と頂堤の存在を認めた。 4 〜 12 日培羑後の上下肢芽に特いては主として間葉細胞の一定の增殖とそ の部位のトルイジン青の異調染色性, 血管形成, 胎生結合織の発現を認めたが, 骨原基の出現は認めなか 
つた。第 2 段階では培養前の肢芽では全例に括いて頂堤が存在し，上腕骨要るいは大腿骨原基が20６0\% の肢芽に执いて認められた。また血管形成もなされていた。培養 4 〜 18 日後の上肢では主として尺骨, 撓 骨, 手根骨原基の出現, 下肢では大腿骨の他に脛骨㧍よび腓骨原基の出現を認めた。上腕骨拉よび大腿骨 原基では軟骨化を認めた。胎生結合織の発現および骨格筋原基の発現も認めた。第 3 段階では培息前の肢 芽に扔いては上下肢芽共に軟骨化した骨原基の出現, 血管形成抢よび胎生結合織の存在を認めた。培養後 4〜10日の上下肢芽では骨原基の軟骨分化度が進行し, 各骨原基間の関節形成初期像を認めた。また殆ん ぞの例において骨格筋原基の出現を認めた。

以上の結果からヒト胎芽期肢芽の培養が可能で一定の分化成長の進行基準を定められることが判明し た。同時に培養下ではヒト肢芽の分化成長は母体内に拉けると比較し著るしく遅延することも判明した。 またマウス胚肢芽の器官培養の結果と比較すると培養下に括けるとトでの 4 日間の分化成長はマウスに括 いて相当する発育段階の肢芽の 1 日間の分化成長に該当し, 催奇形検查に応用出来ると考える。

\section{論文審查の結果の要旨}

本論文は諸種の実験動物やとトの胎児の相互の間には薬物に対する感受性の差異がしばしば示されるこ とに鑑みて, 培養下のヒトの器官原基を以てする検索法の実用性を呤味したものである。材料としては優 生保護法に則って行なわれた人工妊娠中絶に由来する受精後約 4 〜 週柃の胎芽86例をあてた。

これを一定期間冷蔵した上，その上又は下肢芽を採取し，一部は直ちに，大部分は Wolff と Haffen 法 （1952）の変法により培養した上，H．E．染色法とトルイジン青染色法により組織学的検索を行なった。 その結果，生体に抢けるものと類似した分化，即ち間葉上り軟骨，骨原基その他支持組織（骨格筋，血 管など）の形成に至るまでの進行が認められた。また，尗速度は生体におけるものよりもおをく，別に

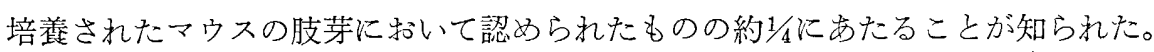

以上の研究はヒトの肢芽の培養法が発生薬理学的又は発生生化学的研究などの手段として有用であるこ とを示したもので, 従来困難とされていたヒトに拉ける諸問題の打開に寄与するものと認められる。

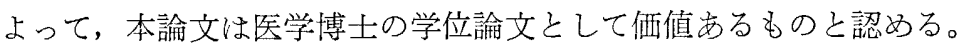

